\section{The transient syndrome of headache with neurological deficits, cerebrospinal fluid pleocytosis and acute confusional state: a case report}

\author{
${ }^{1}$ A. Giorgetti (西) • ${ }^{1}$ G. Mariani $・{ }^{2}$ G.M. Patruno \\ ${ }^{2}$ A. Romorini \\ ${ }^{1}$ Department of Neurology, \\ Legnano Hospital, \\ Via Candiani 2, I-20025 Legnano, Italy \\ E-mail: andrea.giorgetti@ao-legnano.it \\ Tel.: +39-0331-449554 \\ Fax : +39-0331-449558 \\ ${ }^{2}$ Neurology Service, \\ Magenta Hospital, \\ Milan, Italy
}

Published online: 15 December 2005

\begin{abstract}
The syndrome of transient Headache and Neurological Deficits with cerebrospinal fluid Lymphocytosis (HaNDL) now referred to in the IHS ICHD-II code 7.8 , is only infrequently accompanied by a confusional state and severe agitation. We report the case of a 34-year-old man who suffered from three episodes of headache with transient focal neurological deficits that were consistent with HaNDL but that were accompanied by an intense, confusional agitated state that required admission, in the first episode, in a psychiatric unit.
\end{abstract}

Keywords HaNDL • Migraine headache

\section{Introduction}

Syndrome of transient Headache and Neurological Deficits with cerebrospinal fluid Lymphocytosis (HaNDL) was first described by Bartleson et al. in 1981 [1]. In the second edition of the International Classification of Headache Disorders (ICHD-II) HaNDL was defined and classified in Group 7, "headache attributed to non-vascular intracranial disorder" code 7.8 [2].

\section{Case report}

A 34-year-old man was referred to our emergency department in 1992 (the first time), then in 1998 and in 2005 (the last episode). In 1992 our patient showed behavioural disorders followed by an intense confusional agitated state accompanied by a severe and diffuse headache that required admission to the Psychiatry Department with diagnosis of acute confusional state. In 1998, our patient showed speech disturbances; the day after he appeared confused, with unchanged speech disturbances.

In 2005, awaking in the morning the patient felt strange; later on becoming restless, undressing and dressing; then becoming aphasic and agitated. When he came to the Emergency Department he appeared confused and agitated, with speech disturbances, complaining of severe, diffuse headache. In all three episodes the patient fully recovered in $24-48 \mathrm{~h}$.

\section{Discussion}

All the episodes lasted several hours and were accompanied by confusional state, with no signs of meningeal irritation. The focal neurologic deficits (aphasia and sensory symptoms) were temporary with complete recovery. In two cases fever was present. On two occasions cerebrospinal fluid lymphocytosis and elevation of total protein were observed. Computerised tomography and magnetic resonance imaging were normal. Extensive microbiological determinations were negative: routine haematological, immunological, blood and urine tests were normal. EEG showed diffuse slow waves not localised in areas consistent with the focal neurological deficits. Due to the clinical similarities, other diagnoses such as migraine with aura, familial hemiplegic migraine and all the headaches attributed to infectious and non-infectious inflammatory disease should be considered [2]. However, in this case we remark upon the particular five uncommon conditions: presence of previous attacks of migraine with aura and family history of migraine; severe, intense, prolonged, acute confusional state [3]; presence of fever; the first relapse happened after six years; and the temporal pattern: 3 episodes distributed over 12 years.

\section{References}

1. Bartleson JD, Swanson JW, Whisnant JP (1981) A migrainous syndrome with cerebrospinal fluid pleocytosis. Neurology $31: 1257-1262$

2. Headache Classification Subcommittee of the International Headache Society (2004) The international classification of headache disorders, 2nd Edn. Cephalalgia [Suppl 1]:9-160

3. Mateo I, Pinedo A, Gomez-Beldarrain M, Garcia-Monco JC (2004) Acute confusional state secondary to transient headache and neurological deficits with cerebrospinal fluid lymphocytosis. Neurologia 19(10):763 